\title{
Possible new role for angiotensin- converting enzyme inhibitors in treating glomerulonephritis
}

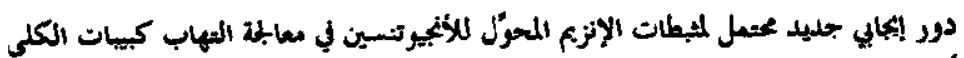

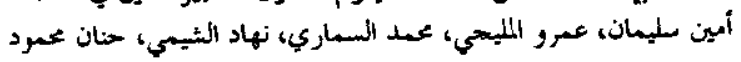

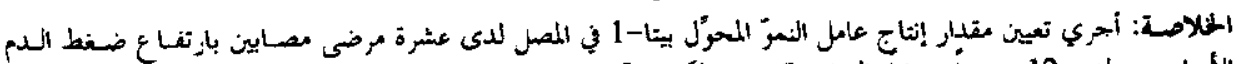

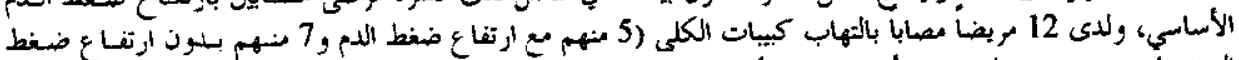

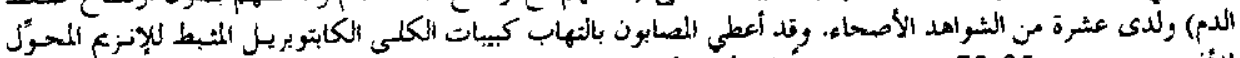

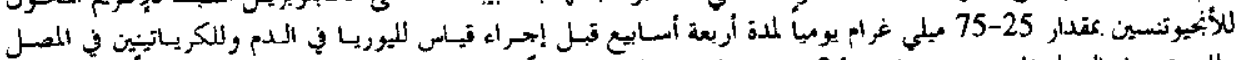

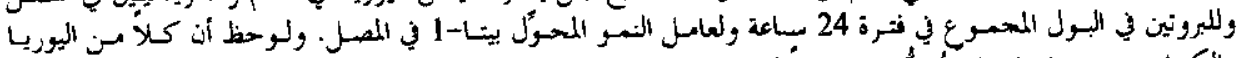

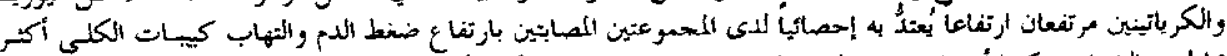

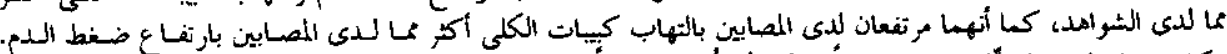

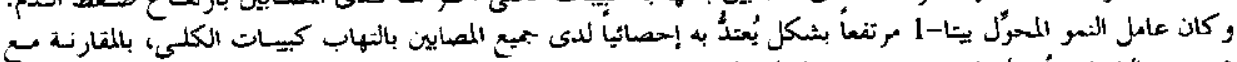

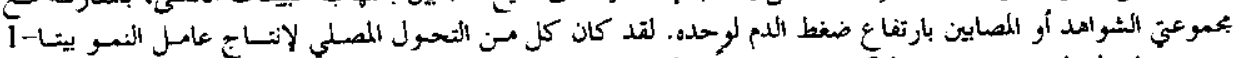

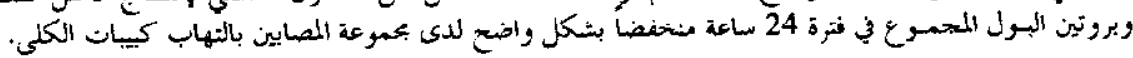

ABSTRACT Serum transforming growth factor-beta (TGF-p1) production was estimated for 10 patients with essential hypertension, 12 patients with glomerulonephritis (5 hypertensive and 7 normotensive) and 10 healthy controls. The glomerulonephritis group received angiotensin-converting enzyme inhibitor captopril $25.75 \mathrm{mg} /$ day for 4 weeks. Blood urea, serum creatinine, 24-hour urinary protein and serum TGF-B1 were then re-estimated. Urea and creatinine were significantly higher is the hypertension and glomerulonephritis groups than in the controls and also higher in the glomerulonephritis group than the hypertension group. TGF- $\beta 1$ was significantly higher in the glomerulonephritis groups than in the control and hypertension groups. TGF- $\beta 1$ and 24 -hour urinary protein were significantly reduced in the glomenulonephritis group.

Nouveau rôle possible pour les inhibiteurs de l'enzyme de conversion de l'angiotensine dans le traitement de la glomérulonéphrite

RESUME La production du facteur de croissance transformant-bêta sérique (TGF- $\beta 1$ ) a été évaluée chez 10 patients atteints dhypertension artérielie essentielle, 12 patients atteints de glomérulonéphrite (5 hypertendus et 7 normotendus) et 10 témoins en bonne santè. Le groupe atteint de glomérulonéphrite a reçu l'inhibiteur de l'enzyme de conversion de l'angiotensine captopril 25-75 mg/jour pendant quatre semaines. L'urée sanguine, la créatininémie, la protéinurie 24 heures et le TGF- $\beta 1$ sérique ont été alors réévalués. Les taux d'urée et de créatinine dans le groupe de patients atteints d'hypertension et de glomérulonéphrite étaient significativement plus élevés que ceux du groupe témoin et is étaient également plus élevés dans le groupe atteint de glomérulonéphrite que ceux du groupe souffrant d'hypertension. Les taux de facteur de croissance TGF- $\beta 1$ étaient significativement plus élevés dans le groupe de patients atteints de glomérulonéphrite que ceux du groupe témoin et du groupe souffrant d'hypertension. Les taux de TGF- $\beta 1$ et la protéinurie 24 heures étaient significativement réduits dans le groupe de patients atteints de glomérułonéphrite.

'Departments of Intemal Medicine and Clinical Pathology, Faculty of Medicine, University of Cairo, Cairo, Egypt.

Received: 28/10101; accepted: 21/02/02

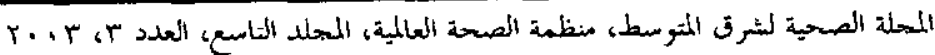




\section{Introduction}

There is experimental and human evidence that inhibition of the renin-angiotensin system by angiotensin-converting enzyme inhibitors (ACE-I) consistently reduces urinary protein excretion rate and retards the development of renal injury [I]. Thus, in rats with subtotal nephrectomy, in diabetic rats and in male Munich Wistar Fromter/Ztm (MWF/Ztm) rats that spontaneously develop renal failure with age, ACE-I are effective in reducing blood pressure, proteinuria and glomerulosclerosis [2]. Also they give comparable protection in immunologic models of progressive renal disease (passive Heymann nephritis in the rat) that closely resemble human membranous nephropathy [3]. Together these data can be taken to suggest that reducing angiotensin II (Ang II) activity protects from the development of proteinuria and renal injury [4]. Besides lowering intraglomerular pressure [5], improving glomerular size selectivity [6] and limiting mesangial cell proliferation and matrix synthesis by direct action of Ang II [7], autocrine activation of growth factors is another possible mechanism [8]. Thus Ang II potentially induces in the kidney the expression of transforming growth factorbeta (TGF- $\beta$ ) [8], a cytokine involved in cell proliferation, monocyte migration and matrix synthesis [9].

TGF- $\beta$ is important in wound healing and tissue repair. Overproduction of TGF$\beta$ can result in excessive deposition of scar tissue and fibrosis [10]. TGF- $\beta$ stimulates the deposition of extracellular matrix by different mechanisms: TGF- $\beta$ stimulates directly the synthesis of extracellular matrix molecules including fibronectin, collagen and proteoglycan and blocks the degradation of matrix by inhibiting the secretion of proteases and stimulating the production of protease inhibitors. TGF- $\beta$ also modulates the expression of integrin matrix receptors on cells in a manner that facilitates cell matrix adhesion and matrix deposition. It also autoinduces its own secretion [II].

This study determined the serum level of TGF- $\beta 1$ in patients with essential hypertension and in patients with glomerulonephritis and demonstrated the effect of ACE-I on TGF- $\beta 1$ levels, degree of protenuria and kidney function in patients with glomerulonephritis.

\section{Methods}

Patients who were scheduled for routine follow-up in the general medicine and nephrology outpatient clinics of Kasr alAini Hospital, Cairo, Egypt, were included in this study. All patients were subjected to full history taking, full clinical examination, urine analysis, blood urea [12], serum creatinine [13], fasting and two-hour postprandial blood glucose [14] and urine examination for microalbuminuria [15]. Patients who were positive for microalbuminuria had their urine examined for 24-hour urinary protein. Patients with serum creatinine more than $3 \mathrm{mg} / \mathrm{dL}$ or pyuria and those receiving ACE-I were excluded.

The patients were divided into two groups. Group I comprised 10 patients with essential hypertension without microalbuminuria ( 5 males and 5 females). Their mean age was $52.4 \pm 10.5$ years. Clinical examination revealed left ventricular hypertrophy in 3 patients and accentuated second heart sound A2 in 5 patients. Fundus examination was normal for all.

Group II comprised 12 patients with glomerulonephritis (5 males and $7 \mathrm{fe}$ males). Of these, 7 patients had lupus

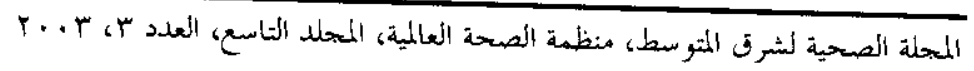


nephritis, 3 patients had focal segmental glomerulonephritis and 2 had membranous nephritis; diagnosis was made according to renal biopsy. Their mean age was $39.8 \pm 8.4$ years. Clinical examination revealed hypertension in 5 and normal blood pressure in 7 . Nine patients had lower limb oedema. Fundus examination was normal for all patients.

Ten healthy persons ( 6 males and 4 females) of mean age $48 \pm 6.9$ years served as the control group.

Serum TGF- $\beta 1$ was estimated for all subjects. The glomerulonephritis group received the ACE-I captopril 25-75 mg/day for four weeks to keep systolic pressure between $110-140 \mathrm{mmHg}$ and diastolic pressure between $70-90 \mathrm{mmHg}$. Blood urea, serum creatinine, 24-hour urinary protein excretion and serum TGF- $\beta 1$ were then re-estimated.

The TGF- $\beta$ enzyme-amplified sensitivity immunoassay (EASIA) (MedGenix, Brussels) was used. This is a solid phase enzyme-immunoassay performed on microtitre plates, in which a fixed amount of TGF- $\beta$ labelled with horseradish peroxidase (HRP) competes with unlabelled TGF- $\beta 1$ present in standard or extracted samples for a limited number of binding sites on a specific coated antibody. After 2 hours incubation at room temperature with continuous shaking, the microtitre plate was washed to stop the competition reaction. The chromogenic solution tetramethylbenzidine (TMB) was added and incubated for 30 minutes. The reaction was stopped with the addition of stop solution and the microtitre plate was read at the appropriate wavelength. The amount of the substrate was determined calorimetrically by measuring the absorbance that was inversely proportional to TGF- $\beta$ concentration. A standard curve was plotted and the TGF- $\beta 1$ concentration in the samples was determined by interpolation from the standard curve [16].

Data were analysed using SPSS, version 8. Quantitative data were analysed using Student t-test for comparison means of two groups. Paired t-test was used to compare between means before and after intervention. Values less than 0.05 were significant. The Pearson correlation coefficient was used to express the relationship between TGF- $\beta 1$ and variables $[17]$.

\section{Results}

The laboratory data of all groups was collected (Table 1). There were significantly higher blood urea $(P<0.03)$ and creatinine $(P<0.02)$ levels in the essential hypertension group than in the controls. There were significantly higher urea $(P<$ $0.01)$ and creatinine $(P<0.01)$ levels in the glomerulonephritis group than in the controls. Furthermore, there were significantly higher urea $(P<0.04)$ and creatinine $(P<0.03)$ in the glomerulonephritis group than the hypertension group.

TGF- $\beta 1$ levels in all groups are given in Table 2 . TGF- $\beta 1$ was significantly higher in the hypertension and glomerulonephritis groups and in the glomerulonephritis subgroups (hypertensive and normotensive) than in the controls $(P<0.001)$. There was significant higher TGF- $\beta 1$ in the total glomerulonephritis group and in the subgroups (with and without hypertension) than in the essential hypertension group $(P<0.001)$. There was no significant difference in TGF- $\beta 1$ between the hypertensive and normotensive glomerulonephritis patients.

The effects of ACE-I captopril in glomerulonephritis patients are given in Table

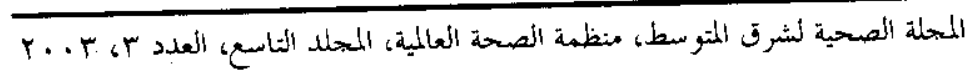



Table 1 Blood urea, serum creatinine and blood glucose levels of controls and
study groups of patients

\begin{tabular}{lrcc}
\hline Test & Controls & $\begin{array}{c}\text { Essential hyper- } \\
\text { tension group }\end{array}$ & $\begin{array}{c}\text { Glomerulo- } \\
\text { nephritis group }\end{array}$ \\
\hline Blood urea (mg/dL) & $24.50 \pm 5.00$ & $43.10 \pm 14.60$ & $58.00 \pm 32.60^{\circ, 0}$ \\
Serum creatinine $(\mathrm{mg} / \mathrm{dL})$ & $0.90 \pm 0.16$ & $1.07 \pm 0.10^{\circ}$ & $1.50 \pm 0.60^{\circ, 0}$ \\
Fasting blood glucose $(\mathrm{mg} / \mathrm{dL})$ & $82.60 \pm 8.50$ & $89.50 \pm 12.57$ & $89.00 \pm 11.60$ \\
$\begin{array}{l}\text { Two-hour postprandial blood } \\
\text { glucose }(\mathrm{mg} / \mathrm{dL})\end{array}$ & $96.90 \pm 10.13$ & $107.00 \pm 27.30$ & $104.80 \pm 13.50$ \\
\hline
\end{tabular}

Values are mean levels \pm standard deviation.

${ }^{a} \mathrm{P}<0.05$, diseased groups versus controls.

¿P $<0.05$, essential hypertension group versus glomerulonephritis group.

\begin{tabular}{|c|c|c|}
\hline \multirow[t]{2}{*}{ Group } & \multirow{2}{*}{$\begin{array}{l}\text { No. of } \\
\text { patients }\end{array}$} & \multirow{2}{*}{$\begin{array}{c}\text { TGF- } \beta 1 \text { levels } \\
\text { (ng/dL) }\end{array}$} \\
\hline & & \\
\hline Controls & 10 & $36.3 \pm 12.9$ \\
\hline $\begin{array}{l}\text { Essential hyperte } \\
\text { group }\end{array}$ & 10 & $80.4 \pm 18.2^{\mathrm{a}}$ \\
\hline $\begin{array}{l}\text { Glomerulonephri } \\
\text { group }\end{array}$ & 12 & $386.7 \pm 88.8^{\mathrm{a}, \mathrm{b}}$ \\
\hline Hypertensive & 5 & $393.3 \pm 92.2^{\mathrm{a}, \mathrm{b}}$ \\
\hline Normotensive & 7 & $379.1 \pm 83.5^{a . b}$ \\
\hline
\end{tabular}

3 . There were significant reductions in 24 hour urinary protein and TGF- $\beta 1$ after giving captopril to these patients $(P<0.005$ and $P<0.001$, respectively). There were no significant changes in urea and creatinine.

There was no significant correlation between TGF- $\beta 1$ and 24 -hour urinary protein in patients with glomerulonephritis.

\section{Discussion}

In the present study we found significantly higher TGF- $\beta 1$ in patients with essential hypertension than in the control group. Our results agree with $\mathrm{Li}$ et al. [18] and Suthanthiran et al. [19]. Suthanthiran et al. found higher plasma TGF- $\beta 1$ and mRNA in hypertensive patients compared with normotensive subjects. They concluded that TGF- $\beta 1$ hyperexpression is a risk factor for hypertension and hypertension complications. Moreover, $\mathrm{Li}$ et al. found a significant positive correlation of TGF- $\beta 1$ circulating levels and blood pressure. Their observation supported the idea that genetically determined TGF- $\beta 1$ concentrations may play a role in blood pressure regulation in humans via stimulation of endothelin I and/or renin secretion [ $/ 8]$.

In the present study, patients with glomerulonephritis (total and subgroups) had significantly higher serum TGF- $\beta 1$ than normal healthy controls. Kanai et al. [20] found increased urinary excretion of TGF- $\beta$ in patients with focal segmental glomerulonephritis and with lupus nephritis but not in IgA nephropathy and memb-

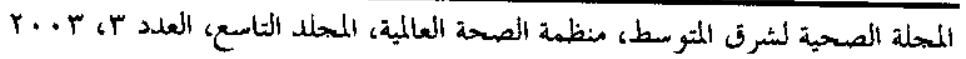




\begin{tabular}{|c|c|c|c|}
\hline Test & $\begin{array}{c}\text { Before captopril } \\
\text { treatment }\end{array}$ & $\begin{array}{c}\text { After captopril } \\
\text { treatment }\end{array}$ & P-value \\
\hline Blood urea (mg/dL) & $58.0 \pm 32.7$ & $60.5 \pm 38.4$ & NS \\
\hline Serum creatinine (mg/dL) & $1.5 \pm 0.6$ & $1.6 \pm 0.0$ & NS \\
\hline 24-hour urinary protein ( $g /$ day) & $4.4 \pm 3.1$ & $2.6 \pm 1.6$ & $<0.005$ \\
\hline Serum TGF- $\beta 1$ (ng/dL) & $386.7 \pm 88.8$ & $306.4 \pm 60.0$ & $<0.001$ \\
\hline
\end{tabular}

Values are mean levels \pm standard deviation. NS = not significant.

ranous glomerulonephritis. Honkanen et al. [2l] found significantly increased urinary excretion of TGF- $\beta$ in patients with membranous nephritis compared with healthy controls. Experimental and human studies have demonstrated that renal injury is associated with increased expression of TGF- $\beta 1$ by glomerular mesangial cells and that increased production of TGF- $\beta$ plays a key role in renal fibrosis [22]. An increased glomerular TGF- $\beta$ staining was observed in human renal biopsies of 10 patients with post-streptococcus glomerulonephritis [23]. It has been reported that increased renal expression of TGF- $\beta$ after renal injury occurs in response to many factors such as Ang II, hypoxia, autoantibodies and the immune complex [24].

In the present study TGF- $\beta 1$ was significantly higher in patients with glomerulonephritis than in patients with essential hypertension without renal involvement. TGF- $\beta 1$ was also elevated in our patients with glomerulonephritis both with and without hypertension. Therefore, a factor or factors other than hypertension causes elevation of TGF- $\beta 1$ in glomerulonephritis. A possible factor may be related to Ang II because of the reduction of TGF- $\beta 1$ levels in serum in our study after treatment with
ACE-I captopril. It has been reported that Ang II is a potent inducer of TGF- $\beta 1$. The induction of TGF- $\beta$ by Ang II is a protein kinase C-dependent effect, similar to TGF$\beta 1$ induction by glucose [25]. Also Ang II may play a role in glomerular TGF- $\beta 1$ autoinduction; thus it may play an outstanding role in the switch of mechanisms that are involved in the healing process of renal lesions. Such action would promote lesion progression towards a chronic fibrotic disease (glomerulosclerosis) rather than remodelling to the original anatomical functional structure. Ang II stimulates renal tubular hypertrophy and mesangial cell and matrix overexpression via autocrine stimulation of TGF- $\beta 1$ in tissue culture [26].

TGF- $\beta 1$ plays a role in the pathogenesis of experimental models of glomerulonephritis. Ang II induces the expression of TGF- $\beta 1$ in the kidney, a cytokine involved in cell proliferation, monocyte migration and matrix synthesis [27]. It has been reported that rat mesangial cells in culture exposed to Ang II increased TGF- $\beta 1$ mRNA and protein, which in turn promoted the synthesis of extracellular matrix [28]. In antithymocyte serum-induced glomerulonephritis in rats (which resembles human IgA nephropathy and mesangial prolife-

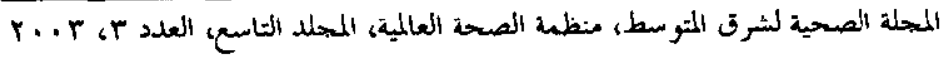


rative forms of lupus nephritis) after a single injection of antithymocyte serum (ATS) there is mesangiolysis and monocyte/macrophage infiltration of glomeruli, followed by mesangial proliferation and matrix expansion, and TGF- $\beta$ is overexpressed in the glomeruli [29]. Treatment with TGF- $\beta 1$ neutralizing antibodies limited the severity of the disease and prevented matrix deposition [30]. TGF- $\beta 1$ induces the synthesis and overexpression of many mitogenic and chemical mediators, such as platelet derived growth factor [31], endothelin I [32] and monocyte chemoattractant protein-I [33] and may contribute to glomerular cell proliferation and monocyte/macrophage recnitment.

The effect of ACE-I on TGF- $\beta 1$ was studied in patients with glomerulonephritis. We found that serum levels of TGF- $\beta 1$ and 24-hour urinary protein decreased significantly with no significant difference in urea and creatinine after treatment with the ACE-I captopril. Our results agree with Peters et al. [22] and Campistol et al. [34]. Peters et al. studied the effect of treatment of experimentally-induced glomerulonephritis in rats with increased doses of the ACE-I enalapril or the Ang II antagonist losartan. Six days after disease induction, the therapeutic effect on the glomerular TGF- $\beta 1$ overexpression was evaluated. Both enalapril and losartan reduced TGF$\beta 1$ overproduction in a dose-dependent manner. Campistol ct al. [34] studicd the effect of losartan on the plasma level of TGF- $\beta 1$ in renal transplant patients with chronic allograft nephropathy. They found that losartan significantly decreased the plasma levels of TGF- $\beta 1$ and concluded that these results could play a dccisive role in treatment and prevention of chronic nephropathy and not only graft nephropathy.

The mechanism by which ACE-I reduces the serum TGF- $\beta 1$ level is unknown. It is likely that inhibition of ACE levels leads to reduction of Ang II, which would lower the production of TGF- $\beta 1$ in a variety of cell types. In cell culture studies, Ang II stimulates mRNA and protein levels [35]. Zoja et al. [4] studied the effects of ACE-I lisinopril and Ang II receptor antagonist L158,809 in rats with ATS-induced glomerulonephritis. Both were effective in preventing proteinuria and reduced glomerular cell proliferation and macrophage infiltration and prevented the formation of microaneurysms. These effects were associated with reduction in glomerular TGF- $\beta 1$ mRNA expression and with normalization of excessive urinary excretion of TGF- $\beta 1$ that likely reflects the renal synthesis of the protein. Thus, ATS-blocking Ang II synthesis or activity prevents proteinuria and, by reducing excessive renal TGF- $\beta 1$, possibly limits glomerular cell proliferation and inflammatory cell infiltration.

It can be concluded that TGF- $\beta 1$ is elevated in patients with essential hypertension and chronic glomerulonephritis. Use of ACE-I may reduce proteinuria and TGF$\beta 1$. Reduction of TGF- $\beta 1$ is a possible mechanism of reduction of proteinuria in patients with glomerulonephritis; however, the effects of other mechanisms cannot be ruled out. 


\section{References}

1. Zoja $C$ et al. Passive Heymann nephritis: evidence that angiotensin-converting enzyme inhibition reduces proteinuria and retards renal structural injury. Experimental nephrology, 1996, 4:21321.

2. Remuzzi A et al. Comparison of the effects of angiotensin-converting enzyme inhibition and angiotensin receptor blockade on the evolution of spontaneous glomerular injury in male MWF/Ztm rats. Experimental nephrology, 1996, 4:1925.

3. Zoja $\mathrm{C}$ et al. The renoprotective properties of angiotensin-converting enzyme inhibitors in a chronic model of membranous nephropathy are solely due to the inhibition of angiotensin. 11: Evidence based on comparative studies with a receptor antagonist. American journal of kidney disease, 1997, 29:25464.

4. Zoja $C$ et al. Pharmacologic control of angiotensin $\|$ ameljorates renal disease while reducing renal TGF- $\beta$ in experimental mesangioproliferative glomerulonephritis. American journal of kidney disease, 1998, 31:453-63.

5. Meyer TW et al. Reversing glomerular hypertension stabilizes established glomerular injury. Kidney international, 1987, 31:752--9.

6. Remuzzi A et al. Effect of low dose enalapril on glomerular size selectivity in human diabetic nephropathy. Journal of nephrology, 1993, 6:36-43.

7. Woif G, Haberstroh U, Neilson EG. Angiotensin II stimulates the proliferation and biosynthesis of type I collagen in cultured murine mesangial cells. American journal of pathology, 1992. 140:95-107.
8. Kagami $S$ et al. Angiotensin II stimulates extracellular matrix protein synthesis through induction of transforming growth factor- $\beta$ expression in rat mesangial cells. Journal of clinical investigation, 1994, 93:2431-7.

9. Border WA, Noble NA. Transforming growth factor- $\beta$ in tissue fibrosis. New England journal of medicine, 1994, 331:1286-92.

10. Singer AJ, Clark RAF. Cutaneous wound healing. New England journal of me. dicine, 1999, 341:738-46.

11. Roberts AB, Sporn MB. Differential expression of TGF- $\beta$ isoforms in embryagenesis suggests specific roles in developing and adult tissues. Molecular reproduction and development, 1992, 32:91-8.

12. Chaney AL, Marbach EP. Modified reagents for determination urea and ammonia. Clinical chemistry, 1962, 8:130-2.

13. Bowers LD, Wong ET. Kinetic serum creatinine assay. A critical evaluation and review. Clinical chemistry, 1980 , 926:555.

14. Trinder $P$. Determination of blood glucose using an oxidase-peroxidase system with non-carcinogenic chromogen. Journal of clinical pathology, 1969 , 22:158-61.

15. Ljungman S. Microalbuminuria in essential hypertension. American journal of hypertension, 1990, 3:956-60.

16. Danielpour $D$ et al. Sandwich enzymelinked immunosorbant assays (SELISAs) quantitate and distinguish two forms of transforming growth factorbeta (TGF-beta1 and TGF-beta2) in

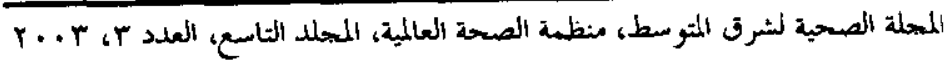


complex biological fluids. Growth factors, 1989, 2:61-71.

17. Norusis MJ. SPSS for windows. Base system users guide, release 5 . Chicago, SPSS Inc, 1992.

18. Li B et al. TGF-b1 DNA polymorphisms, protein levels and blood pressure. Hypertension, 1999, 33:271-5.

19. Suthanthiran $T$ et at. Transforming growth factor-beta 1 hyperexpression in African-American hypertensives: a novel mediator of hypertension and/or target organ damage. Hypertension, 2000. 28:3479-84.

20. Kanai $H$ et al. Increased excretion of transforming growth factor-beta in patients with focal glomerular sclerosis. Nephron, 1997, 66:391-5.

21. Honkanen $E$ et al. Urinary transforming growth factor $\beta 1$ in membranous glomerulonephritis. Nephrology, dialysis, transplantation, 1997, 12:2562-8.

22. Peters $\mathrm{H}$ et al. Targeting TGF- $\beta$ overexpression in renal diseases. Kidney international, 1998, 54:1570-80.

23. Mezzano $Z$ et al. Immunohistochemical Iocalization of IL-8 and TGF- $\beta 1$ in streptococcal glomerulonephritis. Journal of the American Society of Nephrology, 1997, B(2):234-41.

24. Border WA, Noble NA. Angiotensin II in renal fibrosis. Hypertension, 1998, 31: 181-8.

25. Gibbons GH, Pratt RE, Dzau VJ. Vascular smooth muscle cell hypertrophy vs. hyperplasia: Autocrine transforming growth factor- $\beta 1$ expression determines growth response to angiotensin II. Journal of clinical investigation, 1992, 90:456-61.

26. Cheng HF, Bums KD, Harris RSC. Reduced proximal tubular angiotensin II receptor expression mice induced DM. Kidney intermational, 1995, 46:1603-10.

27. Border WA. Noble NA. Transforming growth factor $\boldsymbol{B}$ in tissue fibrosis. New
England journal of medicine. 1994, $331: 1286-92$.

28. Kagami S et al. Angiotensin II stimulates extracellular matrix protein synthesis through induction of transforming growth factor $\beta$ expression in rat glomerular mesangial celis. Journal of clinical investigation, 1994, 93:2431-7.

29. Okuda $S$ et al. Elevated expression of transforming growth factor $\beta$ and proteoglycan production in experimental glomerulonephritis. Possible role in expansion of mesangial extracellular matrix. Journal of clinical investigation, 1990, 86:453-62.

30. Border WA et al. Suppression of experimental glomerulonephritis by antiserum against transforming growth factor B1. Nature, 1990, 346:371-4.

31. lida $\mathrm{H}$ et al. Platelet-derived growth factor (PDGF) and PDGF receptor are induced in mesangial proliferative nephritis in the rat. Proceedings of the National Academy of Sciences of the United States of America, 1991, 88:6560-4.

32. Yoshimura $A$ et al. Endothelin-1 and endothelin B type receptor are induced in mesangial proliferative nephritis in the rat. Kidney international, 1995, 48: 1290-7.

33. Staht RAK et al. Increased expression of monocyte chemoattractant protein-1 in anti-thymocyte antibody-induced giomerulonephritis. Kidney international, 1993, 44:1036-47.

34. Campistol $\mathbf{N}$ et al. Losartan decreases the plasma levels of TGF- $\beta 1$ in transplant patients. Kidney international, 1999 , 56:714-9.

35. Ziyadeh FN et al. Stimulation of collagen gene expression and protein synthesis in murine mesangial cells by high glucose is mediated by activation of TGF- $\beta$. Journal of clinical investigation, 1994, 93:536-42. 